\title{
Translation of Murine Leukemia Virus RNA in Cell-Free Systems from Animal Cells
}

\author{
IAN M. KERR'* UDY OLSHEVSKY, HARVEY F. LODISH, AND DAVID BALTIMORE \\ Department of Biology and Center for Cancer Research, Massachusetts Institute of Technology, Cambridge, \\ Massachusetts 02139
}

Received for publication 8 December 1975

\begin{abstract}
The virion RNA of Moloney murine leukemia virus (MuLV) has been translated in eukaryotic cell-free systems derived from mouse L- and human $\mathrm{HeLa}$ cells. In both systems at least three polypeptides, approximately $60,000,70,000$, and 180,000 in apparent molecular weight, were formed in response to the added $35 S$ MuLV RNA. All three polypeptides were precipitable with antiserum to detergent-disrupted MuLV. Fingerprint analysis of tryptic digests indicated that all three contain amino acid sequences in common with each other and with the major methionine-containing structural proteins of the virion.
\end{abstract}

The genome of the RNA tumor viruses is made up of two to three apparently identical RNA molecules, each of molecular weight $2.5 \times$ $10^{6}$ to $3 \times 10^{6}$, sufficient to encode polypeptide(s) of total molecular weight 250,000 to 300,000 . The RNA carries the genetic information for the major virion antigens, glycoprotein(s), and reverse transcriptase, which amounts to about 200,000 in molecular weight. It is not yet clear, however, if this is all that is coded (reviewed in ref. 2).

As a direct approach to determining the information content of the genome, the virion RNAs have been isolated from a number of oncornaviruses and translated in a variety of cell-free systems $(9,19,23,25,28)$. One major Rous sarcoma virus (RSV)-specific polypeptide of molecular weight 70,000 to 80,000 was synthesized in response to RSV RNA in a cell-free system from Krebs II ascites tumor cells (28). In addition, Naso et al. (19) have reported that the translation of Rauscher murine leukemia virus (RLV) RNA in extracts of starved RLV-infected cells yielded at least two classes of polypeptides of 50,000 to 70,000 and 140,000 to 185,000 in molecular weight.

Here we report an investigation of the translation of Moloney murine leukemia virus (MuLV) RNA in cell-free systems from mouse and human cells. At least three major polypeptides of apparent molecular weight 60,000 , 70,000 , and 180,000 on electrophoresis in sodium dodecyl sulfate (SDS)-polyacrylamide gels were formed in response to the added MuLV RNA. An initial immunological charac-

\footnotetext{
1 Present address: The National Institute for Medical Research, London N.W.7 1AA, England.
}

terization and tryptic fingerprint analysis of these products is presented.

\section{MATERIALS AND METHODS}

Chemicals for use in the cell-free system and for the isolation of cell fractions and viral RNA were as described previously $(8,10-13)$. Spermidine (neutralized with $\mathrm{HCl}$ ) was from Sigma Chemical Co., St. Louis, Mo.; $\left[{ }^{35} \mathrm{~S}\right]$ methionine $(100$ to $450 \mathrm{Ci} / \mathrm{mmol})$ was from New England Nuclear Corp., Boston, Mass.; encephalomyocarditis virus (EMC) was from G. D. Searle and Co., Ltd., High Wycombe, Bucks, England; TPCK trypsin was from Worthington Biochemical Corp., Freehold, N.J.; and rabbit anti-goat $\gamma$ globulin was from Microbiological Associates, Bethesda, Md. Goat antiserum to detergent (tweenether)-disrupted Moloney MuLV was obtained from the National Cancer Institute, Bethesda, Md. (NCI ID 1-S-0157).

Cells, virus, and viral RNA. Clone 1 Moloney MuLV was derived and maintained as previously (7). Clone 2 was obtained from clone 1 by end point dilution of the virus on NIH-3T3 cells with immediate cloning of the cells after infection (M. Paskind, D. Smotkin, and D. Baltimore, unpublished data). For large-scale production of rapid-harvest virus, productively infected cells were grown in roller bottles in Dulbecco modified Eagle medium (DME) with $10 \%$ calf serum. Virus was purified from medium collected at 4-h intervals. This was clarified by centifugation at $1,000 \times g$ for $15 \mathrm{~min}$ at $4 \mathrm{C}$, and the virus was pelleted at $27,000 \times g$ for $2.5 \mathrm{~h}$. The virus was resuspended in TNE [ $50 \mathrm{mM}$ tris(hydroxymethyl)aminomethane (Tris)-hydrochloride ( $\mathrm{pH}$ 7.2), $100 \mathrm{mM} \mathrm{NaCl}, 1 \mathrm{mM}$ ethylenediaminetetraacetic acid] and centrifuged through a 25 to $45 \%$ (wt/wt) sucrose gradient in TNE for $17 \mathrm{~h}$ at 82,000 $\times g$ at $4 \mathrm{C}$. The banded virus was pooled, diluted threefold with TNE, pelleted by further centrifugation for $30 \mathrm{~min}$ at $160,000 \times g$, and resuspended in TNE to a protein concentration of approximately 
$20 \mathrm{mg} / \mathrm{ml}$. SDS was added to a final concentration of $2 \%$ prior to centrifugation for $2.5 \mathrm{~h}$ at $160,000 \times$ $g$ at $22 \mathrm{C}$ through a 15 to $30 \%$ (wt/wt) sucrose gradient in TNE, $1 \%$ SDS. The $70 S$ virion RNA was pooled and precipitated by the addition of two volumes of ethanol. It was taken up in $2 \mathrm{mM}$ sodium

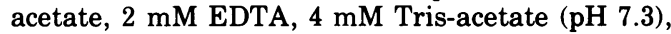
$0.2 \%$ SDS, and denatured by heating for $2 \mathrm{~min}$ at $78 \mathrm{C}$ (5). The heat-denatured virion RNA was centrifuged for $5 \mathrm{~h}$ at $160,000 \times g$ at $22 \mathrm{C}$ through a 15 to $30 \%(\mathrm{wt} / \mathrm{wt})$ sucrose gradient in TNE and $1 \%$ SDS. The $35 S$ RNA was pooled and precipitated with ethanol. The precipitate was washed three times with a mixture of two parts ethanol to one part $100 \mathrm{mM}$ sodium acetate $(\mathrm{pH} 6)$, dissolved in water to a final concentration of 0.5 to $1 \mathrm{mg} / \mathrm{ml}$, and stored at $-70 \mathrm{C}$.

The growth and purification of EMC virus and the preparation of EMC RNA have already been described $(11,13)$.

[ ${ }^{35}$ S]methionine-labeled MuLV. Clone 1 cells were labeled at $37 \mathrm{C}$ in DME with $10 \%$ dialyzed calf serum, $0.75 \mathrm{mg}$ of cold methionine per liter, and 10 to $15 \mu \mathrm{Ci}$ of $\left[{ }^{35} \mathrm{~S}\right]$ methionine per liter. After $2 \mathrm{~h}$ the medium was collected, and the cells were incubated for a further $2 \mathrm{~h}$ in DME and $10 \%$ calf serum. The two batches of medium were pooled, and the radioactive virus was purified as above.

Preparation of cell extracts and the assay of amino acid incorporation in the cell-free system. The preparation and preincubation of postmitochondrial supernatant fractions from mouse L-cells were as described (8). The post-mitochondrial supernatant fractions were dialyzed for $6 \mathrm{~h}$ at $4 \mathrm{C}$ against three changes of $10 \mathrm{mM} \mathrm{N}$-2-hydroxyethylpiperazine$N^{\prime}$-2-ethanesulfonic acid (HEPES) (pH 7.5), $90 \mathrm{mM}$ $\mathrm{KCl}, 1.5 \mathrm{mM}$ magnesium acetate, and $7 \mathrm{mM} \mathrm{2-}$ mercaptoethanol (one hundred volumes in all) to reduce the endogenous pool of amino acids. Assay of amino acid incorporation was in $15-\mu l$ reaction mixtures containing: $20 \mathrm{mM}$ HEPES (pH 7.5); 75 mM (for MuLV RNA) or 110 mM (for EMC RNA) $\mathrm{KCl}$; $\mathrm{mM}$ (for MuLV RNA), or $2 \mathrm{mM}$ (for EMC RNA) magnesium acetate; $0.15 \mathrm{mM}$ spermidine; $8 \mathrm{mM}$ 2-mercaptoethanol; $1 \mathrm{mM}$ ATP; $0.15 \mathrm{mM}$ GTP; $0.6 \mathrm{mM}$ CTP; $10 \mathrm{mM}$ creatine phosphate; 0.16 $\mathrm{mg}$ of creatine kinase per $\mathrm{ml} ; 0.2$ to $0.9 \mathrm{mCi}$ of [ $\left.{ }^{35} \mathrm{~S}\right]$ methionine per $\mathrm{ml}$; unlabeled amino acids (each $100 \mu \mathrm{M})$ minus methionine; $3 \mu \mathrm{l}$ of L-cell extract (equivalent to approximately $50 \mu \mathrm{g}$ of protein); and 1 $\mu \mathrm{l}$ of reticulocyte ribosome wash-initiation factors $(16,22)$. The amounts of different preparations of the L-cell extract and reticulocyte factors used were adjusted for optimum amino acid incorporation in each case. The addition of the reticulocyte initiation factors had no detectable effect on the nature of the polypeptide products synthesized but increased the level of both endogenous and MuLV or EMC RNAstimulated amino acid incorporation two- to threefold. MuLV or EMC RNAs were added to final concentrations of 20 to 60 or 12 to $20 \mu \mathrm{g} / \mathrm{ml}$, respectively. Incubation was for $120 \mathrm{~min}$ at $30 \mathrm{C}$ unless otherwise stated. Preincubated and dialyzed postmitochondrial supernatant fractions from HeLa and Krebs II mouse ascites tumor cells were prepared and assayed as for the L-cell extracts.
Immune precipitation. All sera were clarified by centifugation for $10 \mathrm{~min}$ at $2,000 \times g$ before use. Samples $(10 \mu \mathrm{l})$ of the cell-free system were diluted with an equal volume of TNE, $1 \%$ NP40 and 1\% sodium deoxycholate and allowed to interact with 5 $\mu \mathrm{l}$ of goat anti-MuLV or control serum for $10 \mathrm{~min}$ at room temperature and then overnight at $4 \mathrm{C}$. The mixture was diluted to $0.5 \mathrm{ml}$ with TNE containing $1 \%$ NP40 and $40 \mu$ l of rabbit anti-goat $\gamma$ globulin serum and incubated as above. The precipitate was pelleted at $2,000 \times g$ for $10 \mathrm{~min}$, washed three times with TNE- $0.5 \%$ NP40 and once with acetone, and analyzed by electrophoresis on polyacrylamide gels.

Polyacrylamide gel electrophoresis. The polypeptides synthesized in the cell-free systems were precipitated with acetone, dissolved by boiling in $2 \%$ SDS, $70 \mathrm{mM}$ 2-mercaptoethanol, $62.5 \mathrm{mM}$ Tris-hydrochloride (pH 6.8), $20 \%$ glycerol, and analyzed by electrophoresis on $10 \%$ polyacrylamide slab gels containing $0.1 \%$ SDS (14). Up to 25 samples, each equivalent to 3 to $5 \mu$ l of cell-free system, could conveniently be run on a single gel. Alternatively, the acetone-precipitated polypeptide products were either redissolved in $8 \mathrm{M}$ urea, $1 \%$ SDS, $170 \mathrm{mM} 2-$ mercaptoethanol, $5 \mathrm{mM}$ Tris-glycine, or in $1 \%$ SDS, $100 \mathrm{mM} 2$-mercaptoethanol, $50 \mathrm{mM}$ sodium phosphate ( $\mathrm{pH} \mathrm{7}$ ), boiled for 2 to $3 \mathrm{~min}$, and analyzed on cylindrical $7.5 \%$ polyacrylamide gels containing $0.1 \%$ SDS in the presence or absence of $5 \mathrm{M}$ urea as described by McDowell and Joklik (15) and Weber and Osborn (29), respectively.

Analysis of tryptic peptides. Tryptic digestion of ${ }^{35}$ S-labeled purified MuLV and of the total polypeptide products synthesized in the cell-free system in response to EMC RNA was carried out after precipitation and performic acid oxidation as described previously (4), except that TPCK trypsin equivalent to a total $20 \%$ by weight of the product to be digested was used. Trypsin digestion of individual polypeptides was carried out on individual bands cut from the stained dried gels after exposure for autoradiography (17). The dried gel slices were swollen in a slight excess by volume of TPCK trypsin $(50 \mu \mathrm{g} /$ $\mathrm{ml}$ ) and $0.2 \mathrm{M} \mathrm{NH}_{4} \mathrm{HCO}_{3}(\mathrm{pH} \mathrm{8.5)}$ and incubated overnight at $37 \mathrm{C}$ and for a further $4 \mathrm{~h}$ with a fresh batch of trypsin. Recovery of radioactivity from the gel slices was greater than or equal to $70 \%$. The peptide digests were lyophilized and resuspended in 10 to $20 \mu \mathrm{l}$ of $0.3 \% \mathrm{NH}_{4} \mathrm{OH}$, and $0.2-$ to $1.5-\mu \mathrm{l}$ samples were subjected to electrophoresis and chromatography on precoated thin-layer $(0.1 \mathrm{~mm})$ cellulose plates (Brinkman Instruments Inc., Westbury, N.Y.) as described previously (4), except that electrophoresis at $\mathrm{pH} 3.5$ was in pyridine-acetic acidwater $(1: 10: 100)$.

Autoradiography of the dried polyacrylamide gels and thin-layer plates was with Kodak XOmat film RP R54.

\section{RESULTS}

Electrophoretic analysis of polypeptide products. To investigate whether MuLV RNA can stimulate the synthesis of characteristic polypeptides, 35S RNAs of clone 1 and clone 2 MuLV derived by heat denaturation of virion 
RNA were added to cell-free systems from mouse L-cells. After electrophoretic separation of the ${ }^{35}$ S]methionine-labeled products, three major MuLV RNA-stimulated polypeptides were evident on autoradiography of the dried gels. These had apparent molecular weights of $60,000,70,000$, and $180,000(60 \mathrm{~K}, 70 \mathrm{~K}$, and $180 \mathrm{~K}$, arrowed Fig. 1A). Occasionally the $60 \mathrm{~K}$ and $70 \mathrm{~K}$ products migrated as poorly resolved doublets. Essentially identical results were obtained irrespective of whether the electrophoretic analysis was carried out in slab gels after denaturation in SDS and mercaptoethanol (Fig. 1A) or in cylindrical gels in the presence or absence of additional $8 \mathrm{M}$ urea $(15,29$; data not shown). At the relatively low $\mathrm{K}^{+}$ion concentration optimum for the translation of MuLV RNA in the L-cell-free system $(70 \mathrm{mM}$ compared with $110 \mathrm{mM}$ for EMC RNA), there is a relatively high level of endogenous amino acid incorporation (slot 1, Fig. 1A) and only a two- to threefold stimulation in response to the added MuLV RNA. Under all of the conditions tested here, however, the L-cell-free system yielded more MuLV-specific polypeptide of higher molecular weight than did the wheat germ (21), Krebs ascites tumor cell, rabbit reticulocyte (26), or the partially purified Krebsreticulocyte (1) cell-free systems (data not presented). The HeLa cell-free system yielded the same products as did the L-cell-free system, but in smaller amounts.

The virion RNA of MuLV already has at its $5^{\prime}$-end a 7-methylguanosine residue in $5^{\prime}-5^{\prime}$ triphosphate linkage to the remainder of the RNA (J. Rose, personal communication). In accord with this, the addition of $S$-adenosylmethionine or of $S$-adenosylhomocysteine was without significant effect on amino acid incorporation or the spectrum of polypeptides formed in response to MuLV RNA in these systems.

Kinetics of formation of the MuLV-specific polypeptides in the L-cell-free system. To determine the time course of appearance of the
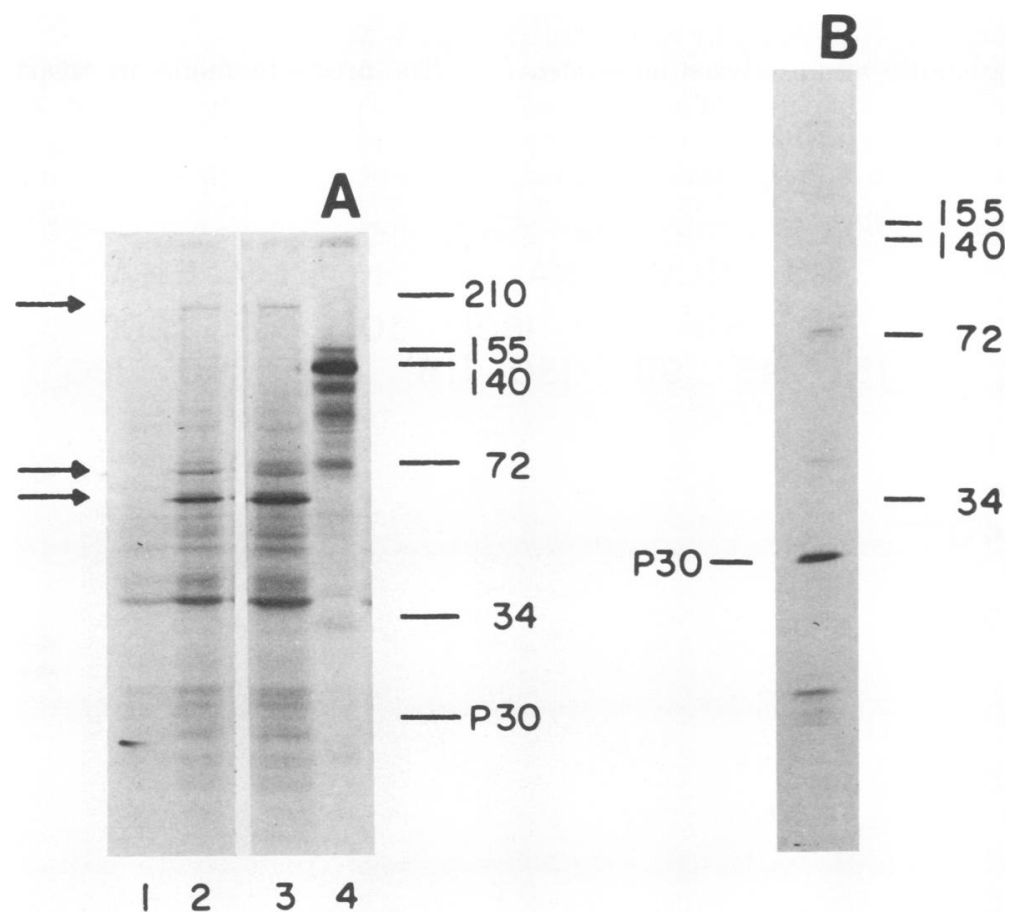

FIG. 1. Electrophoretic analysis of cell-free system products and the polypeptides of purified $M u L V$. (A) $L$ cell-free system products in the presence and absence of MuLV RNA or EMC RNA. Slot 1, minus MuLV RNA (42,000 counts/min); slots 2 and 3, plus MuLV RNA clone 1 and clone $2(95,000$ and 70,000 counts/min, respectively); slot 4, plus EMC RNA (130,000 counts/min); minus EMC RNA (not shown, 3,000 counts/min). Each RNA was assayed under optimum conditions for that RNA (Materials and Methods). Material equivalent to $3 \mu$ l of each cell-free system was analyzed by electrophoresis on a $10 \%$ acrylamide slab gel. (B) ${ }^{[35}$ S methionine-labeled $M u L V$ was subjected to electrophoresis on a gradient ( 8 to $20 \%$ acrylamide) slab gel. For both $A$ and $B$ an autoradiograph of part of the stained, dried gel is shown, and the numbers to the right give the molecular weights in thousands of chick myosin and the major reovirion polypeptides $\lambda 1, \lambda 2, \mu 2$, and $\sigma 3$ (24), which were included as nonradioactive markers. The $60 \mathrm{~K}, 70 \mathrm{~K}$, and $180 \mathrm{~K} M u L V R N A-$ programmed products in $(A)$ are indicated by the arrows to the left. 
three new polypeptides, samples of extracts incubated for various times were submitted to electrophoresis (Fig. 2). The $60 \mathrm{~K}$ product was first evident at $30 \mathrm{~min}$ and the $180 \mathrm{~K}$ at $90 \mathrm{~min}$, as would be expected for newly initiated polypeptides of these sizes in this type of system. The higher-molecular-weight EMC and poliovirus RNA-directed polypeptide products, for example, require comparable times for their synthesis in vitro (Fig. 3 in reference 6; I. M. Kerr, unpublished data). Translation in vivo is considerably faster, but complete translation of these latter RNAs takes $12 \mathrm{~min}$ even at $37 \mathrm{C}$ in the intact infected cell $(3,20)$.

Immunological characterization. The precipitability by a MuLV-specific antiserum of the polypeptide products stimulated by $\mathrm{MuLV}$ RNA was tested to determine if they were virus-specific. Using a HeLa cell-free system, $\left[{ }^{35} \mathrm{~S}\right]$ methionine-labeled products were made with and without added MuLV RNA. They were exposed to goat antiserum against detergent-disrupted MuLV, and material reacting with the serum was precipitated by rabbit antigoat immunoglobulin and analyzed by electrophoresis on polyacrylamide gels. Whereas a few background polypeptides were carried down by both immune and non-immune sera, all three of the MuLV RNA-stimulated polypeptides were precipitated only by the anti-MuLV serum and not by the corresponding control material (Fig. 3). Essentially identical results were obtained with L-cell extracts on similar immunological analysis of the products formed in response to the MuLV RNA (data not shown).

Fingerprint analysis of tryptic peptides. For analysis of the tryptic digests of the MuLVspecific products, the $60 \mathrm{~K}, 70 \mathrm{~K}$, and $180 \mathrm{~K}$, [ ${ }^{35}$ S]methionine-labeled polypeptide bands were eluted from stained dried polyacrylamide gels by digestion with trypsin (17; Materials and Methods). Autoradiographs of two-dimensional thin-layer fingerprints of these digests were compared with that obtained with a similar digest of the $130 \mathrm{~K}$ to $140 \mathrm{~K}$ polypeptide product formed in response to EMC RNA in the Lcell-free system and with those for digests of the total virion polypeptides of purified MuLV, the major MuLV group-specific antigen (P30) and the major small $\left[{ }^{35} \mathrm{~S}\right]$ methionine-labeled polypeptide of MuLV (presumable P15, Fig. 1B; Fig. 4, 5).

The products made in response to $\mathrm{MuLV}$ RNA were clearly different from those programmed by EMC RNA (Fig. 4). The fingerprints obtained from the $60 \mathrm{~K}$ and $70 \mathrm{~K}$ products,

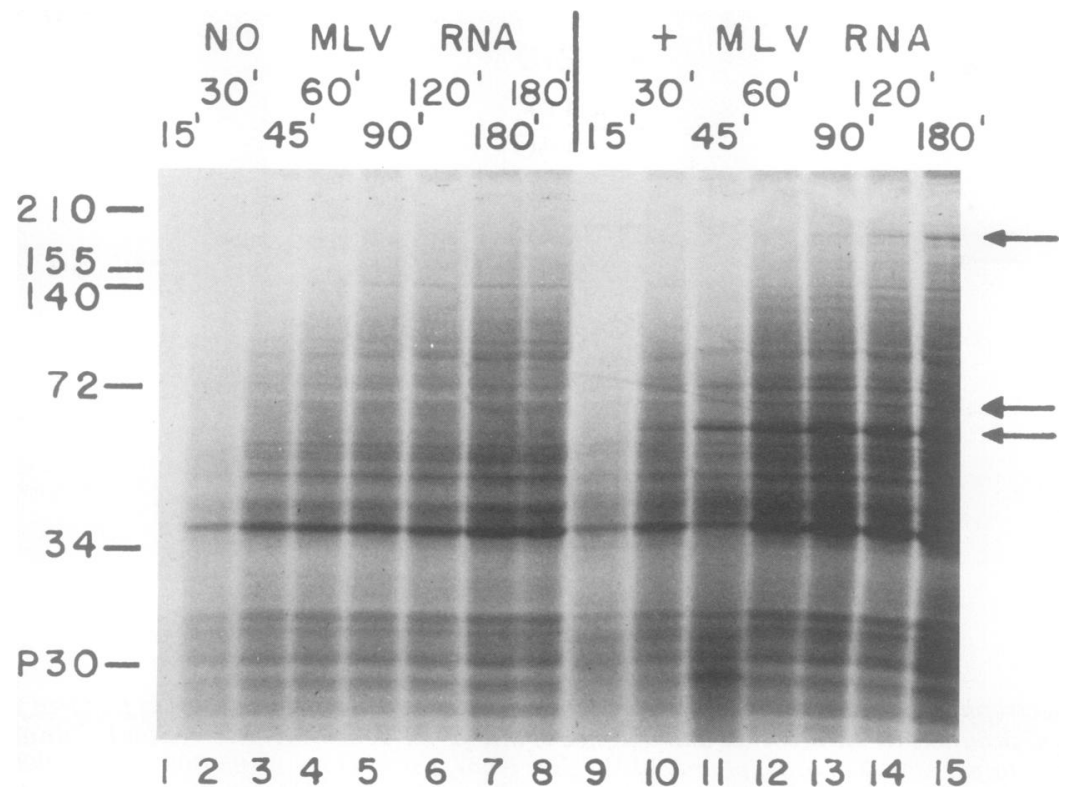

Fig. 2. Synthesis of MuLV-specific polypeptides with time in the cell-free system. L-cell-free systems were incubated in the presence and absence of MuLV RNA. Samples ( $5 \mu l)$ were taken at the times (min) indicated at the top of the figure and analyzed on a $10 \%$ acrylamide slab gel. [ ${ }^{35} \mathrm{~S}$ ] methionine incorporation at 180 min was: minus MuLV RNA 30,000 and plus MuLV RNA 86,000 counts/min per $5 \mu l$. The numbers to the left give the molecular weights in thousands of marker polypeptides as in Fig. 1. The arrows to the right indicate the position of the $60 \mathrm{~K}, 70 \mathrm{~K}$, and $180 \mathrm{~K} M u L V$ RNA-programmed products. 


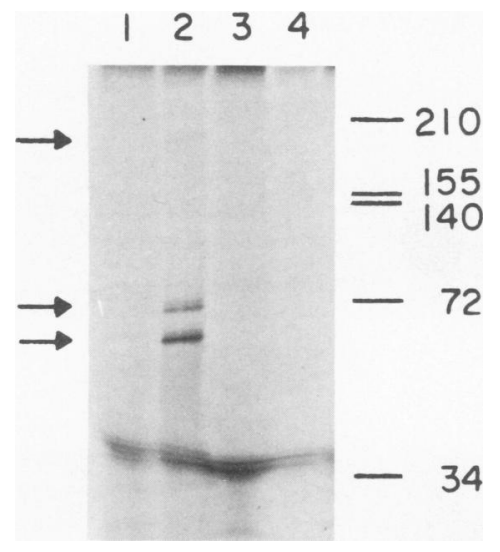

FIG. 3. Immune precipitation of the cell-free system products synthesized in response to MuLV RNA. HeLa cell extracts were incubated in the cell-free system in the presence and absence of MuLV RNA and subjected to immune precipitation. Plus $M u L V$ RNA: slot 1, control serum; slot 2, anti-MuLV serum. No added RNA: slot 3, control serum; slot 4, anti-MuLV serum. Electrophoresis was on a $10 \%$ acrylamide slab gel. An autoradiograph of part of the stained, dried gel is shown. The numbers to the right and the arrows to the left are as described in the legend to Fig. 1.

on the other hand, were indistinguishable and bore no obvious relation to the background material evident in digests of extracts to which no RNA had been added (Fig. 4). All of the tryptic peptides present in the digests of the $60 \mathrm{~K}$ and $70 \mathrm{~K}$ products (Fig. 4A, 4B, 5D) were also evident in the digest of whole virus (Fig. 5A), many of which could be accounted for by those present in the digests of the P30 and P15 (Fig. $5 \mathrm{C}$ and $\mathrm{E}$ ). The fingerprint of the $180 \mathrm{~K}$ product, although closely related to that of whole virus (Fig. 5A), was surprisingly similar to those for the $60 \mathrm{~K}$ and $70 \mathrm{~K}$ products (Fig. $4 \mathrm{~A}, 4 \mathrm{~B}$, and 5D). A few additional MuLV RNA-stimulated peptides have been tentatively identified in the basic region of the $180 \mathrm{~K}$ map, and there could be additional material in the congested band of neutral peptides. The fact remains, however, that for an increase of over 100,000 in apparent molecular weight of the polypeptide from which it was derived, the $180 \mathrm{~K}$ fingerprint shows remarkably little greater apparent complexity than those for the 60 and $70 \mathrm{~K}$ products.

The results in Fig. 4 and 5 were obtained using electrophoresis at $\mathrm{pH}$ 6.5. Despite poorer overall resolution, the general similarities and differences observed with the different digests were essentially confirmed by a further series of fingerprints employing electrophoresis at $\mathrm{pH}$ 3.5 in the first dimension.

\section{DISCUSSION}

At least three polypeptides have been demonstrated to be synthesized in response to $\mathrm{MuLV}$ 35S RNA added to cell-free systems from both human and mouse cells. That these polypeptides are truly MuLV-specific has been shown by their specific immunoprecipitability and by fingerprint analysis of their tryptic peptides. Whereas it is conceivable that the results obtained with mouse L-cell extracts could reflect an increased translation of endogenous mRNA in response to the added RNA, it is extremely improbable that this could be the case with the human HeLa cell extracts. The results obtained with the latter, therefore, clearly show that it is the added MuLV RNA that is directing the synthesis of the three MuLV-specific polypeptides in the cell-free systems. This, in turn, confirms that the virion RNA is the messenger strand for the RNA tumor viruses $(2,19,38)$.

The near identity of the fingerprints of the $60 \mathrm{~K}, 70 \mathrm{~K}$, and particularly the $180 \mathrm{~K}$ products with that for MuLV is striking (Fig. 4, 5). All of the major $\left[{ }^{35} \mathrm{~S}\right]$ methionine peptides present in the $60 \mathrm{~K}$ product are also present in the $70 \mathrm{~K}$, and virtually all are present in the $180 \mathrm{~K}$. It may be, therefore, that these are overlapping polypeptides extending different distances from the same initiation site on the RNA. The peptide sequences common to all three products (those in the 60K) are those of the major structural virion core polypeptides (Fig. 1B, 5). In this sense the $60 \mathrm{~K}$ product may be analogous to the precursor (Pre60) to these latter polypeptides found in the infected cell $(18,27 ; \mathrm{M}$. Paskind and David Baltimore, unpublished data). Similarly, that at $180 \mathrm{~K}$ could correspond to the 140,000 - to 185,000 -molecular-weight precursor reported to be present in intact RLVinfected cells and cell-free systems $(18,19)$.

There are several possible explanations for the apparently small increase (if any) in the complexity of the $180 \mathrm{~K}$ map over those for the $60 \mathrm{~K}$ and $70 \mathrm{~K}$ products. Of these the simplest are (i) aggregation; (ii) tandem repetition of the information for the $60 \mathrm{~K}$ sequences in at least one of the virion RNAs; and (iii) the fact that the sequences additional to the $60 \mathrm{~K}$ sequence in the $180 \mathrm{~K}$ polypeptide are relatively poor in methionine. The time of appearance of the $180 \mathrm{~K}$ product after addition of MuLV RNA to the cell-free system is in accord with its synthesis as a unique polypeptide (Fig. 2). In addition we have no evidence for aggregation in any of the three types of highly denaturing gel system used for the electrophoretic analysis of the products, and preliminary results suggest that comparable amounts of the $60 \mathrm{~K}$, but not of 


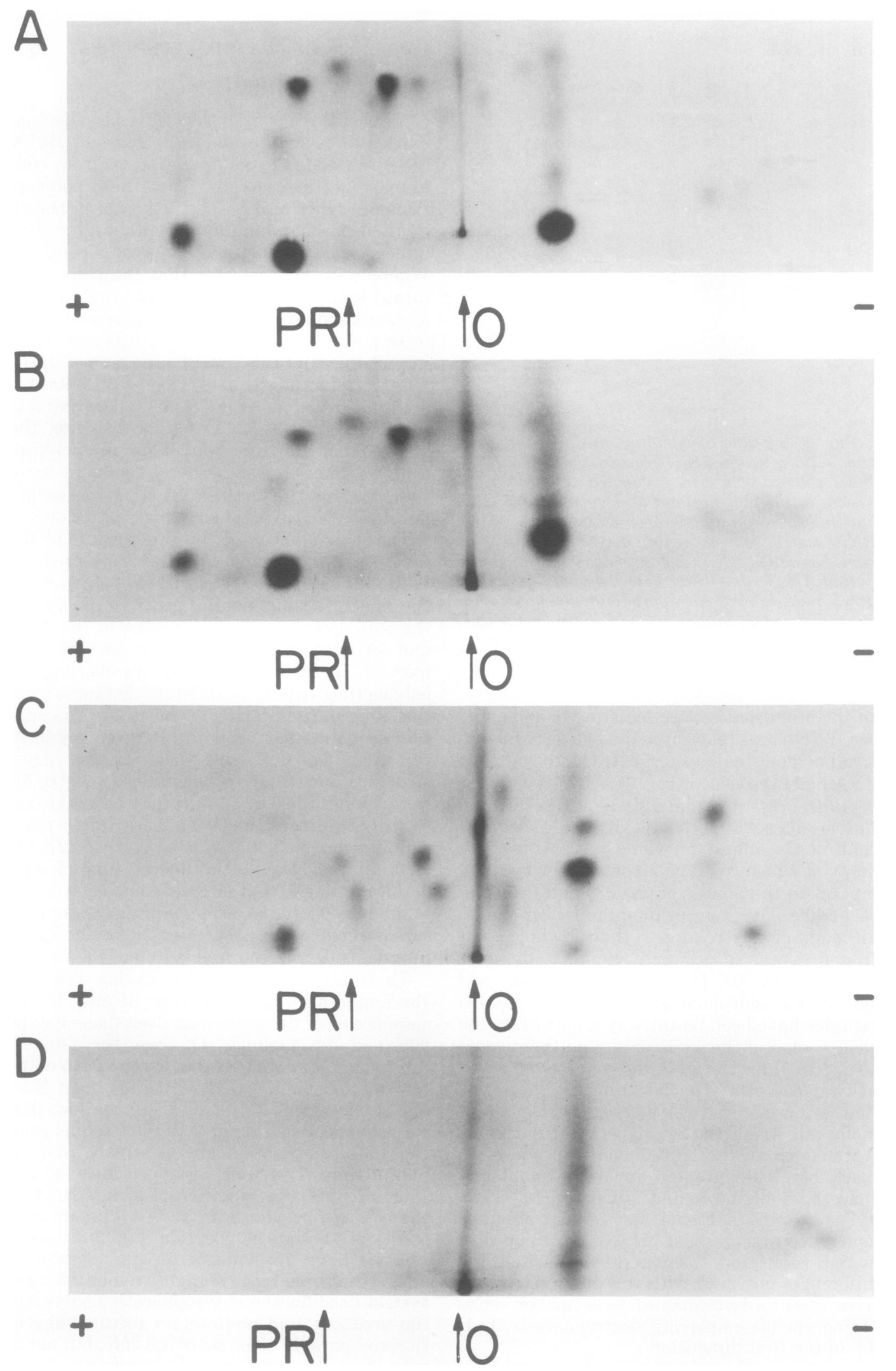

FIG. 4. Fingerprint analysis of tryptic digests of polypeptide products formed in the cell-free system in response to MuLV or EMC RNAs. (A) and (B) Polypeptides (60 and 70K) synthesized in the L-cell-free system in response to MuLV RNA. (C) 130,000- to 140,000-molecular-weight polypeptide synthesized in the same 

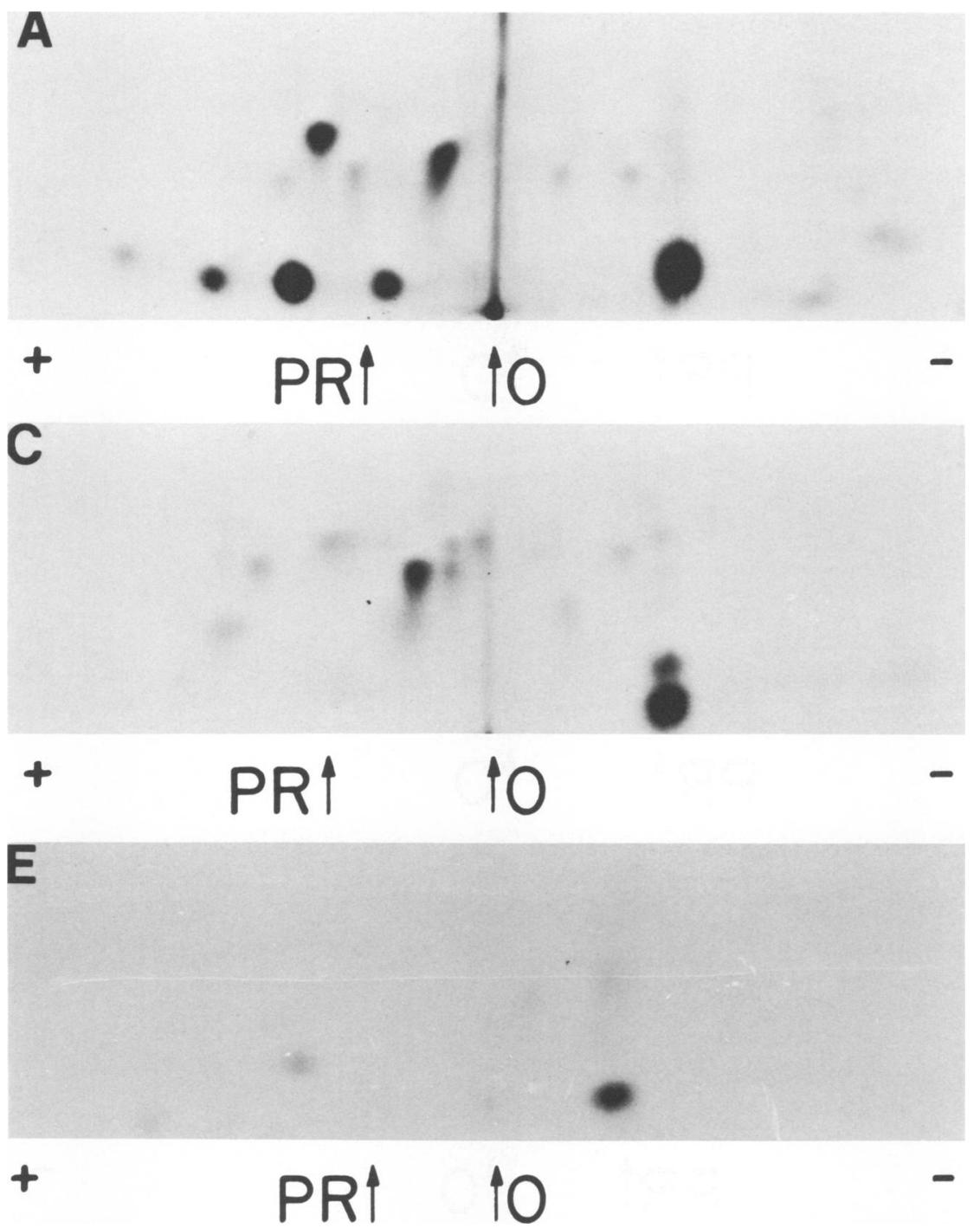

FIG. 5. Fingerprint analysis of tryptic digests of $\left[{ }^{35} \mathrm{~S}\right]$ methionine-labeled $M u L V$, of virion polypeptides, and of MuLV-specific products synthesized in the L-cell-free system. (A) Total MuLV virion polypeptides. (C) and (E) MuLV-virion polypeptides $P 30$ and P15, respectively. (B) and (D) Polypeptides (180K and 60K) synthesized in response to the MuLV RNA in the L-cell-free system. (F) Endogenous polypeptide(s) of 180,000 in molecular weight synthesized in the absence of MuLV RNA under the same conditions as for $B$ and $D$. Loads in counts per minute were $12,000,12,000,7,000,14,000,2,200$, and 6,000 for $A, B, C, D, E$, and $F$, respectively. Autoradiography was for 21 days in all cases. The material used was that described in the legend to Fig. 4.

system in response to EMC RNA. (D) endogenous polypeptide(s) of 60,000 molecular weight synthesized in the absence of MuLV RNA under the same cell-free system conditions as for A and B. After electrophoresis of the cell-free system products as in Fig. 1, individual polypeptide bands were eluted by digestion with trypsin. Samples were applied to the bottom center (O) as shown of thin-layer cellulose plates. Electrophoresis was at pH 6.5 with the anode to the left. PR indicates the position of a phenol red marker. Chromatography was towards the top of the sheet. For direct comparison, two samples were electrophoresed in parallel on the same thin-layer plate which was cut in half for subsequent chromatography. Loads in counts per minute were $18,000,18,000,40,000$, and 6,000 for $A, B, C$, and $D$, respectively. Autoradiography of $A, B$, and $D$ was for 10 days. In this experiment and that shown in Fig. $5,300-\mu l$ reaction mixtures were used in the cell-free system assays. Total recoveries in the final tryptic digests were for plus $M u L V R N A, 60 K, 70 K$, and $180 K$, $440,000,270,000$, and 96,000 counts/min, respectively. In the absence of added RNA the corresponding figures were $120,000,80,000$, and 40,000 counts $/ \mathrm{min}$. 


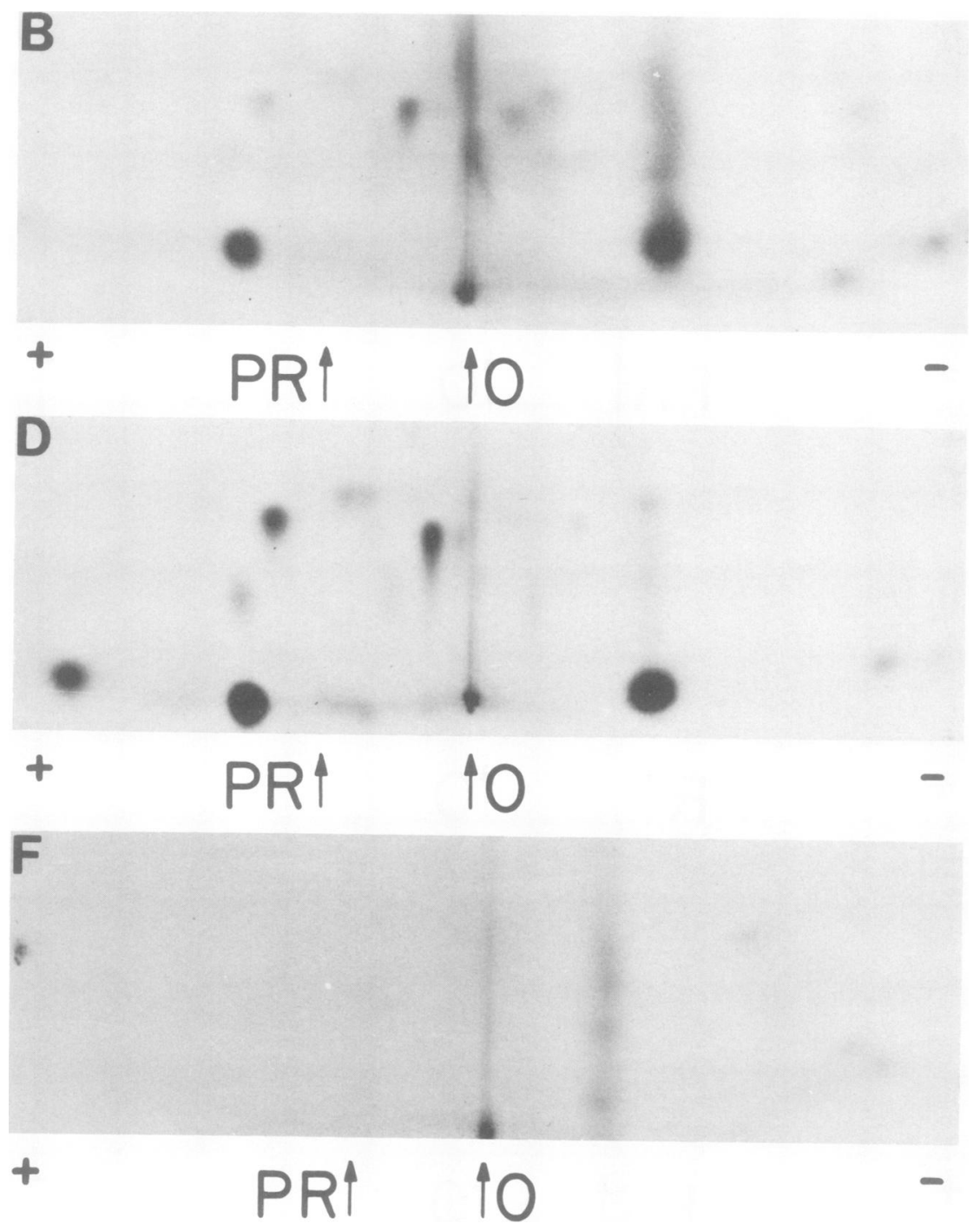

Fig. 5 B, D, F

the $180 \mathrm{~K}$, product can be detected in these systems when smaller fragments of MuLV RNA are used as messenger. Tandem repeats remain an intriguing possibility, but they seem a priori an unnecessary complication. Accordingly, we would currently favor explanation (iii), particularly as the presence of additional non-methionine-containing MuLV-specific amino acid sequences in the $180 \mathrm{~K}$ product can by no means be ruled out at this stage. Which, if any, of these explanations is correct, however, will have to await the results of a more detailed analysis and the identification of all of the sequences present in this highmolecular-weight polypeptide.

\section{ACKNOWLEDGMENTS}

This work was supported by an American Cancer Society Eleanor Roosevelt Cancer Research Fellowship to I.M.K. by U.S. Public Health Service International Fellowship FO5-TW-2135 to U.O., and by Public Health Service grants CA 14051 and AI 08814 from the National Cancer Institute and from the National Institute of Allergy and Infectious Diseases, respectively. D.B. and H.F.L. were recipients of grants VC-4G and NP-180 from the American Cancer Society. D.B. is an American Cancer Society Professor, and H.F.L. is the recipient of N.I.H. Research Career Development award 5-K04-GM50175.

\section{LITERATURE CITED}

1. Anderson, C. W., J. B. Lewis, J. F. Atkins, and R. F. Gesteland. 1974. Cell-free synthesis of adenovirus 2 proteins programmed by fractionated messenger RNA. A comparison of polypeptide products and mes- 
senger RNA lengths. Proc. Natl. Acad. Sci. U.S.A. 71:2756-2760.

2. Baltimore, D. 1975. Tumor viruses 1974. Cold Spring Harbor Symp. Quant. Biol. 39:1187-1200.

3. Butterworth, B. E., and R. R. Rueckert. 1972. Kinetics of synthesis and cleavage of encephalomyocarditis virus-specific proteins. Virology 50:535-549.

4. Dobos, P., I. M. Kerr, and E. M. Martin. 1971. Synthesis of capsid and noncapsid viral proteins in response to encephalomyocarditis virus ribonucleic acid in animal cell-free systems. J. Virol. 8:491-499.

5. Duesberg, P. H., and P. K. Vogt. 1973. RNA species obtained from clonal lines of avian sarcoma and from avian leukosis virus. Virology 54:207-219.

6. Esteban, M., and I. M. Kerr. 1974. The synthesis of encephalomyocarditis virus polypeptides in infected cells and cell-free systems. Eur. J. Biochem. 45:567576.

7. Fan, H., and M. Paskind. 1974. Measurement of the sequence complexity of cloned Moloney murine leukemia virus 60 to $70 S$ RNA: evidence for a haploid genome. J. Virol. 14:421-429.

8. Friedman, R. M., D. H. Metz, M. Esteban, D. R. Tovell, L. A. Ball, and I. M. Kerr. 1972. Mechanism of interferon action: inhibition of viral messenger ribonucleic acid translation in L-cell extracts. J. Virol. 10:1184-1198.

9. Gielkens, A. L. S., M. H. L. Saldens, H. Bloemendal, and R. N. H. Konings. 1972. Translation of oncogenic viral RNA and eukaryotic messenger RNA in the $E$. coli cell-free system. FEBS Lett. 28:348-352.

10. Kerr, I. M., R. E. Brown, and D. R. Tovell. 1972. Characterization of the polypeptides formed in response to encephalomyocarditis virus ribonucleic acid in a cell-free system from mouse ascites tumor cells. J. Virol. 10:73-81.

11. Kerr, I. M., N. Cohen, and T. S. Work. 1966. Factors controlling amino acid incorporation by ribosomes from Krebs 2 mouse ascites tumour cells. Biochem. J. 98:826-835.

12. Kerr, I. M., and E. Martin. 1971. Virus protein synthesis in animal cell-free systems: nature of the products synthesized in response to the ribonucleic acid of encephalomyocarditis virus. J. Virol. 7:438-447.

13. Kerr, I. M., and E. M. Martin. 1972. Simple method for the isolation of encephalomyocarditis virus ribonucleic acid. J. Virol. 9:559-561.

14. Laemmli, U. K. 1970. Cleavage of structural proteins during the assembly of the head of bacteriophage $\mathrm{T} 4$. Nature (London) 227:680-685.

15. McDowell, M., and W. K. Joklik. 1971. An in vitro protein synthesizing system from mouse L-fibroblasts infected with reovirus. Virology 45:724-733.

16. Metafora, S., M. Terada, L. W. Dow, P. A. Marks, and
A. Bank. 1972. Increased efficiency of exogenous messenger RNA translation in a Krebs ascites cell lysate. Proc. Natl. Acad. Sci. U.S.A. 69:1299-1303.

17. Morrison, T. G., and H. F. Lodish. 1975. The site of synthesis of membrane and nonmembrane proteins of vesicular stomatitis virus. J. Biol. Chem. 250:69556962.

18. Naso, R. B., L. J. Arcement, and R. B. Arlinghaus. 1975. Biosynthesis of Rauscher leukemia viral proteins. Cell 4:31-36.

19. Naso, R. B., L. J. Arcement, T. G. Wood, and R. B. Arlinghaus. 1975. The cell-free translation of Rauscher leukemia virus RNA into high-molecular weight polypeptides. Biochim. Biophys. Acta 383:195-206.

20. Rekosh, D. 1972. Gene order of poliovirus capsid proteins. J. Virol. 9:479-487.

21. Roberts, B. E., M. Gorecki, R. C. Mulligan, K. T. Danna, S. Rozenblatt, and A. Rich. 1975. SV40 DNA directs the synthesis of authentic viral polypeptides in a linked transcription-translation cell-free system. Proc. Natl. Acad. Sci. U.S.A. 72:1922-1926.

22. Shafritz, D. A., and W. F. Anderson. 1970. Isolation and partial characterization of reticulocyte factors M1 and M2. J. Biol. Chem. 245:5553-5559.

23. Siegert, W. R. N. H. Konings, $H$. Bauer, and $\mathbf{P}$. $H$. Hofschneider. 1972. Translation of avian myeloblastosis virus RNA in a cell-free lysate of $E$. coli. Proc. Natl. Acad. Sci. U.S.A. 69:888-891.

24. Smith, R. E., H. J. Zweerink, and W. K. Joklik. 1969. Polypeptide components of virions, top component, and cores of reovirus type 3 . Virology 39:791-810.

25. Twardzik, D., J. Simmonds, M. Oskarson, and F. Portugal. 1973. Translation of AKR murine leukemia viral RNA in an $E$. coli cell-free system. Biochem. Biophys. Res. Commun. 52:1108-1114.

26. Villa-Komaroff, L., M. McDowell, D. Baltimore, and H. F. Lodish. 1974. Translation of reovirus mRNA, poliovirus RNA and bacteriophage $Q \beta$ RNA in cellfree extracts of mammalian cells, p. 709-724. In L. Grossman and $\mathbf{K}$. Moldave (ed.), Methods in enzymology, vol. 30. Academic Press Inc., New York.

27. Vogt, V. M., and R. Eisenman. 1973. Identification of a large polypeptide precursor of avian oncornavirus proteins. Proc. Natl. Acad. Sci. U.S.A. 70:1734-1738.

28. Von der Helm, K., and P. H. Duesberg. 1975. Translation of Rous Sarcoma virus RNA in cell-free systems from ascites Krebs 2 cells. Proc. Natl. Acad. Sci. U.S.A. 72:614-618.

29. Weber, K., and M. Osborn. 1969. The reliability of molecular weight determinations by dodecylsulfatepolyacrylamide gel electrophoresis. J. Biol. Chem. 244:4406-4412. 